\title{
TITLE:
}

\section{ON AN INTERESTING NEW GENUS OF GASTROPOD MOLLUSCA FROM THE SEA OF KII PENINSULA}

$\operatorname{AUTHOR}(S):$

Kuroda, Tokubei

\section{CITATION:}

Kuroda, Tokubei. ON AN INTERESTING NEW GENUS OF GASTROPOD MOLLUSCA FROM THE SEA OF KII PENINSULA. PUBLICATIONS OF THE SETO MARINE BIOLOGICAL LABORATORY 1952, 2(2): 69-71

ISSUE DATE:

1952-10-05

URL:

http://hdl.handle.net/2433/174686

RIGHT: 


\title{
ON AN INTERESTING NEW GENUS OF GASTROPOD MOLLUSCA FROM THE SEA OF KII PENINSULA*
}

\author{
TOKUBEI KURODA \\ Zoological Institute, Kyoto University
}

With 4 Text-figures

Among numerous undescribed new genera and species of shells from the Japanese seas, I herewith give the diagnosis of a very interesting new genus. This new species of the genus may probably belong to the family Xancidae (formerly Turbinellidae), which has been represented in Japan by two species of the unique genus Vasum. It is a remarkable fact that the present new genus differs not only widely from that genus, but also its shape shows a resemblance to a member of the family Mitridae, except several important features as described belów.

\section{Ceraioxancus ${ }^{* *}$ genus nov.}

Type, Ceratoxancus teramachii n. sp.

A small shell of about $30 \mathrm{~mm}$ in length, much resembling a Mitridae, however, differing in having a sharp labral horn and an operculum. The radula shows some resemblance to Xancidae.

The presence of a horny spine on the outer lip is frequently met with in the members of the genera Lativus, Ancilla, Busycon and Murex. The present new genus, though provided with such a horn, stands quite apart from the above-named genera, by the presence of distinct columellar folds as seen in Mitridae, and also by the radular character. A. ADAMs" "Melula" cumingi (Proc. Zool. Soc. London, (1853): 173, pl. 20, figs. 1, 2, 1855) from the west coast of Africa has some resemblance in form to this shell, but it is never provided with columellar folds.

* Contributions from the Seto Marine Biological Laboratory, No. 177.

** keras =horn; xancus =chank, the name of a Hindoo sacred shell.

Publ. Seto Mar. Biol. Lab., II (2), 1952. (Article 5) 


\section{Coratoxancus teramachis* sp. nov.}

(Figs. 1-4)

Shell. rather thick, fusiform, produced at both ends, somewhat constricted on the base; spire being contained twonfths in the whole shell length. Whorls moderately convex, retaining $6 \frac{1}{4}$ (several apical ones decollated in the type specimen, but a slightly immature paratype from Tosa bears 8 whorls which also lacking the apical ones), with distinct, sub-tabulated and subcanaliculated suture; sculpture distinctly plicated axially by numerous, rounded and somewhat unequal plicae with much narrower interspaces; the plicae are retractively slanting in front, but they disappear on the last half of the last whorl, which is somewhat roughened by irregular growth striae and inconspicuous spiral threads; the spiral striae are conspicuous on the spire
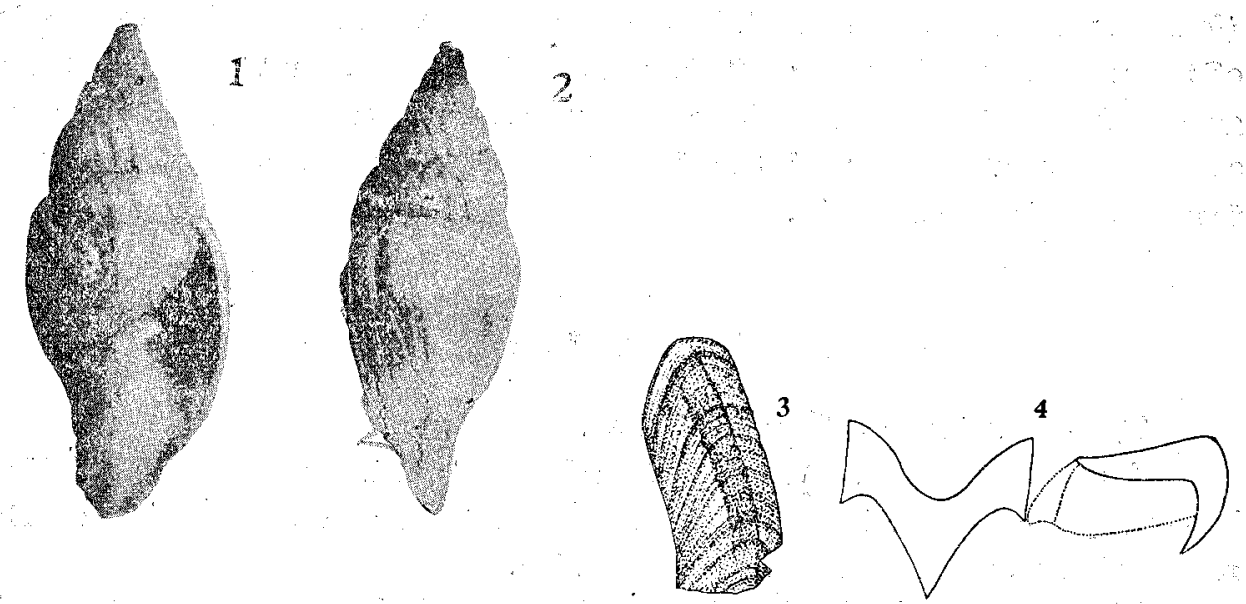

Figs. 1-4. Geratoxancus teramachii. KURODA (gen et sp. nov.) 1. Frontal, 2. right lateral views of the type, $34.6 \times 14 \mathrm{~mm} 3$. Operculum from the paratype; 4 . Rhachidian and lateral teeth of radula from the same. (figs. 3 and 4 were drawn by T. HABE).

whorls, about 12 on a whorl, groovy and more distinct between the axial plicae, but irregular in size and in their arrangements (in the paratype that feature very much resembling some Nassarizs; the second or third groove from above is larger than the rest which forming a subsutural sulcus). Last whorl large and stout, sub-cylindrical below the constriction which is closely provided with spiral rounded threads, the number of which being about 14 including those on the caudal rostration; the umbilical portion excavated,

* Nom. Jap. "Fudegai-modoki." 
bordered by a stout rib of fasciole; aperture narrowly lanceolate; outer lip simple, the margin sharp and retractively oblique towards the base, sinuated at the portion of distance about one-fourth of length of margin from the base, and at the portion just above the sinuation, there is a broken scar of a somewhat sharp horn-like spine which is supposed to be a trace of an immature spine. Canal open and straight; columellar margin straight, provided with 3 somewhat sharp, oblique spiral plicae, the upper ones the larger; the parietal wall oblique, forming an angle at the junction with the outer lip; the throat covered by whitish gray thick enamel. Color of shell somewhat fleshy gray, with an interrupted pale brown zone at the center of the last whorl, and also the base including the caudal rostoration is stained broadly with the same color.

Length of shell 34.6 , of last whorl 25.6 , of aperture 21.8 , diam. of shell 14.0, of aperture $6.4 \mathrm{~mm}$.

Type locality: Off Kii Peninsula, collected by Akibumi Teramachi more than a decade ago; a single type specimen.

Afterwards, Mr. Teramachi collected 2 additional specimens of this interesting rare species from off Tosa (the depth of which supposed to be about 200 fathoms), though both were slightly immature, and one of which contained the animal with an operculum. They wear very thin citrinous yellow periostracum with a slight gloss. The radula has been examined by Mr. T. HABE and here igured by his courtesy. The operculum is delicate, arcuate, dark orangy brown, the terminal nucleus broken off. The measurements of the paratypes from Tosa are as follows:

(1) $30.4 \times 22.4 \times 18.4 \times 12.4 \times 6.5 \mathrm{~mm}$, 8 whorls (apical ones lost).

(2) $27.4 \times 16.5 \times 15.7 \times 10.7 \times 5.9 \mathrm{~mm}$., 8 whorls, also apical ones not preserved. 